\title{
PENGEMBANGAN PETUNJUK PRAKTIKUM BERBASIS MASALAH MEMUAT LITERASI SAINS SISWA SMP KELAS VIII
}

\author{
Lutfi Hamim $^{1 *}$, Dyah Ayu Fajarianingtyas ${ }^{2}$, Jefri Nur Hidayat ${ }^{3}$ \\ ${ }^{1,2,3}$ Program Studi Pendidikan IPA FKIP Universitas Wiraraja,Madura, Indonesia \\ *Corresponding Author: mailto:izzahalfikry@gmail.com
}

DOI: $10.24929 /$ lens.v11i1.155

\begin{abstract}
ABSTRAK
Penelitian ini mengembangkan petunjuk praktikum yang berbasiskan masalah terhadap literasi sains siswa SMP kelas VIII. Jenis Penelitian ini yaitu penelitian dan pengembangan atau R\&D dengan menggunakan model pengembangan 4-D (four D) yang terdiri dari define, desaign, develop, dan disseminate oleh Thiagarajan. Data diambil dari hasil observasi dalam mengetahui kevalidan dan respon guru terhadap petunjuk praktikum berbasis masalah memuat kegiatan yang mendukung literasi sains siswa SMP kelas VIII. Data validitas diperoleh dari hasil validasi materi dan media. Data respon diperoleh dari penyebaran angket respon guru. Hasil validasi bahwa petunjuk praktikum berbasis masalah terhadap literasi sains siswa valid (layak) dengan rata-rata presentase skor sebesar 96,4\% (sangat layak), yang terdiri dari validasi materi dan validasi media. Maka dari itu petunjuk praktikum yang dikembangkan layak untuk digunakan. Hasil angket respon guru terhadap petunjuk praktikum berbasis masalah dari responden memperoleh rata-rata presentase skor sebesar 97,9\% (sangat baik) dan mendapat respon positif dari para responden. Jadi petunjuk praktikum berbasis masalah terhadap literasi sains siswa layak untuk digunakan.
\end{abstract}

Kata kunci: Petunjuk praktikum, pembelajaran berbasis masalah, literasi sains

\begin{abstract}
This study developed practical instructions based on problems in the science literacy of grade VIII junior high school students. This research is a research and development or R\&D with a 4$D$ (four D) development model which consists of Thiagarajan define, design, develop, and disseminate. The data were taken from observations in determining the validity and responses of teachers to problem-based practicum instructions containing activities that support the scientific literacy of grade VIII junior high school students. The validity data obtained from the validation of the material and media. Response data were obtained from distributing teacher response questionnaires. The validation results show that the problem-based practicum instructions for students' scientific literacy are valid (feasible) with an average percentage score of $96.4 \%$ (very feasible), which consists of material validation and media validation. Therefore, the practicum instructions developed are suitable for use. The results of the teacher's questionnaire response to problem-based practicum instructions from respondents obtained an average percentage score of $97.9 \%$ (very good) and received a positive response from the respondents. So problem-based practicum instructions for students' scientific literacy are feasible to use.
\end{abstract}

Keywords: Practicum instructions, problem based learning, science literacy

\section{PENDAHULUAN}

Ilmu yang mempelajari suatu fenomena dan segala sesuatu yang terjadi di alam disebut dengan Ilmu Pengetahuan Alam (IPA). Pembelajaran IPA juga ada kaitannya dengan teknologi dan masyarakat, serta membutuhan kemampuan literasi sains dalam memahami fenomena dan gejala alam yang ada (Prasetyono \& Trisnawati, 2018). Pembelajaran IPA saat ini menekankan pada penyampaian suatu konsep IPA dan penyajian dari penerapan konsep-konsep tersebut pada permasalahan kehidupan sehari-hari. Konsep IPA tersebut dapat ditemukan dari suatu tahapan percobaan. Maka dari itu kegiatan praktikum lebih tepat dalam memberikan materi pada 
pembelajaran IPA (Seftia R.W., et al 2018). Pada suatu kegiatan praktikum terdapat beberapa tatacara atau langkah-langkah yang akan dilakukan mulai mempersiapkan, melaksanakan praktikum, menganalisis data yang diperoleh, yang kemudian ditulis sebagai suatu' laporan praktikum. Beberapa tahapan tersebut yang tersusun secara terstruktur dan mengacu pada prosedur tertentu dapat dikatakan sebagai pedoman atau petunjuk praktikum (Budiarti \& Oka, 2014).

Kegiatan praktikum seharusnya mampu membuat siswa mengembangkan beberapa keterampilan, seperti kemampuan berpikir, kemampuan memecahkan masalah, serta kemampuan melakukan penelitian sebagai suatu keperluan dalam konteks perubahan dunia yang semakin cepat, sehingga pembelajaran berbasis masalah menjadi salah satu konsep pembelajaran di abad ke-21 (Abidin, 2014). Model pembelajaran berbasis masalah ini membuat peserta didik menggali pengetahuannya sendiri dari keterampilannya memecahkan permasalahan dengan berkelompok (Susanti, 2019). Permasalahan dalam situasi nyata dan bermakna bagi siswa dapat menjadi salah satu batu loncatan dalam menginvestigasi dan menyelidiki suatu permasalahan tertentu, hal ini merupakan esensi dari model pembelajaran berbasis masalah (Arends, 2008).

Pada (Asyhari, 2015) pembelajaran saintifik menjadikan kemampuan literasi sains siswa meningkat. Pembelajaran saintifik merangsang siswa terhadap isu-isu ilmiah, penemuan ilmiah, serta memberikan rasa tanggung jawab siswa terhadap lingkungan sekitarnya. Model pembelajaran berbasis masalah dapat membangun literasi sains siswa pada konteks perkembangan dunia seperti sekarang ini. Pada era abad 21 sekarang ini segala sesuatu serba teknologi, hal ini juga ada kaitannya dengan dunia pendidikan pada aspek literasi sains siswa (Pertiwi, Atanti, \& Ismawati, 2018). Literasi sains merupakan bentuk refleksi individu dan suatu kemampuan dalam mencurahkan perhatian pada suatu topik atau gagasan yang berkaitan dengan sains. Permasalahan yang terdapat di lingkungan sekitar juga akan berdampak terhadap kehidupan di masa mendatang yang berkenaan dengan pengetahuan, teknologi, dan pemberdayaan sumber daya manusia dalam mengambil keputusan secara individu dan mampu berpartisipasi dalam perumusan berbagai kebijakan-kebijakan publik (Fajarianingtyas \& Hidayat, 2019).

Laporan Nasional PISA 2018 di Indonesia dari tahun 2000 hingga 2018 terdapat peningkatan dalam skala kecil pada bidang membaca dan sains, pada bidang matematika mengalami peningkatan yang lebih tajam. Meskipun sepanjang periode terjadi peningkatan hingga PISA 2018, skor Indonesia relatif turun pada semua bidang setelah PISA 2018 (Kemendikbud, 2018). Skor PISA 2018 pada bidang sains di atas lebih dari $80 \%$, namun setelah itu terjadi penurunan skor hingga di bawah $80 \%$. Penurunan skor PISA pada bidang sains ini perlu adanya upaya peningkatan literasi sains siswa dari berbagai aspek yang terdapat dalam cakupan sains.

Permasalahan yang dijumpai dilapangan bahan ajar seperti petunjuk praktikum yang ada belum membantu siswa dalam menunjang pemecahan masalah dan aktivitas literasi sains siswa. Maka dari itu penelitian ini mengembangkan suatu petunjuk praktikum berbasis masalah dengan bermuatan literasi sains siswa yang mana dapat diketahui dari validitas dan respon terhadap produk yang dikembangkan.

\section{METODE}

Penelitian pengembangan ini menggunakan metode R\&D (Research and Development). Pada metode R\&D terdapat model dalam pengembangan penelitian ini yakni model 4-D. Adapun langkah-langkah tahapan model 4-D yaitu Define (Pendefinisian), Desaign (Perancangan), Develop (Pengembangan), dan Disseminate (Penyebaran) (Thiagarajan, et al 1974). Subjek penelitian menggunakan guru IPA SMP Tahfidz Al-Amien dan 2 guru IPA sekolah lain.

Prosedur penelitian telah mengacu pada langkah-langkah yang dipaparkan pada prosedur pengembangan 4-D oleh Thiagarajan. Tahap pendefinisian (define), bertujuan untuk mengetahui kebutuhan siswa melalui informasi-informasi untuk digunakan sebagai bahan perencanaan pengembangan suatu produk pada proses pembelajaran yang dipaparkan melalui tahapan analisis awal akhir (front-end 
analysis), analisis peserta didik (leaner analysis), analisis konsep (concept analysis), analisis tugas (task analysisi), perumusan tujuan pembelajaran (specifying instructional objectives). Tahap perancangan (desaign), digunakan untuk membuat draf rancangan dari petunjuk praktikum yang akan digunakan dengan beberapa komponen yang ada didalam petunjuk praktikum meliputi teks dan gambar dengan langkah-langkah meliputi penyusunan standar tes (criterion test construction), pemilihan media (media selection), serta pemilihan format (format selection).

Selanjutnya tahap pengembangan terdapat dua bagian yaitu yang pertama Validasi Ahli (Expert Appraisal) merupakan teknik validasi dengan menggunakan lembar validasi sebagai suatu masukan atau penilaian dari prkatisi atau ahli yang kemudian dilakukan revisi agar produk pengembangan lebih baik dan dikatakan valid. Tahap kedua yaitu Uji Coba Pengembangan (Development Testing) yaitu kegiatan uji coba produk pada skala kelompok kecil yang untuk menghasilkan petunjuk praktikum berbasis masalah memuat literasi sains siswa yang telah direvisi dari masukan para validator. Tahap penyebaran ini bertujuan dalam mengetahui tes dari hasil validasi terhadap perangkat yang dikembangkan, pada tahapan ini meliputi uji validasi (validation testing), pengemasan (packaging), penyebaran dan pemakaian (diffusion and adaption)

Instrumen yang digunakan berupa instrumen non tes yaitu lembar validasi ahli dan angket respon guru. Lembar validasi ahli terdiri dari lembar validasi ahli materi dan lembar validasi ahli media sebagai bahan revisi dari pegembangan petunjuk praktikum berbasis masalah memuat literasi sains siswa. Sedangkan angket repon guru untuk mengetahui pendapat atau respon guru tentang petunjuk praktikum yang dikembangkan peneliti yang nantinya menjadi bahan revisi akhir produk sebelum digunakan secara luas (Sugiyono, 2015).

Teknik analisis data ini merupakan tahapan setelah data yang telah dikumpulkan dan diverifikasi menjadi tabel yang kemudian dianalisis. Penggunan teknik ini disesuaikan dengan tujuan penelitian yang telah ditentukan. Pada peneltian pengembangan ini teknik analisis data meliputi validitas petunjuk praktikum dan respon guru. Validitas petunjuk praktikum disusun agar petunjuk praktikum yang dikembangkan menjadi baik dan dapat digunakan, melalui langkah-langkah merekap data hasil validasi dan dihitung persentase skor dari validator dengan menggunakan rumus 3.1 berikut :

$$
\text { Skor }(\%)=\frac{\text { jumlah skor komponen validasi }}{\text { skor maksimal }} X 100 \%
$$

Rumus 3.1 perhitungan presentase total skor validitas

Berikut merupakan tabel kriteria yang telah dikembangkan sebagai berikut (Sunarti, 2018):

Tabel 3.2 Kriteria Kelayakan

\begin{tabular}{cc}
\hline Kriteria & Kategori \\
\hline $80 \% \leq$ skor $<100 \%$ & Sangat Layak \\
\hline $60 \% \leq$ skor $<80 \%$ & Layak \\
\hline $40 \% \leq$ skor $<60 \%$ & Kurang Layak \\
\hline $20 \% \leq$ skor $<40 \%$ & Tidak Layak \\
\hline $0 \% \leq$ skor $<20 \%$ & Sangat Tidak Layak \\
\hline
\end{tabular}

Angket respon guru dibuat terhadap petunjuk praktikum yang dikembangkan dengan langkah-langkah merekap hasil penyebaran angket respon dari respoden dan menghitung presentase rata-rata skor yang diberikan responden. Perolehan hasil angket respon guru dihitung menggunakan rumus 3.2 :

$$
\operatorname{Skor}(\%)=\frac{\text { jumlah skor mentah yang diperoleh }}{\text { skor maksimal }} \times 100 \%
$$

Rumus 3.2 perhitunga presentase rata-rata skor respon 
Skor yang diperoleh kemudian dikonversikan dalam bentuk tabel sebagai berikut (Meyhandoko, 2013) :

Tabel 3.3 Kriteria Angket Respon Guru

\begin{tabular}{cc}
\hline Interval & Kriteria \\
\hline $81,25 \% \leq$ skor $<100 \%$ & Sangat Baik \\
\hline $62,50 \% \leq$ skor $<81,25 \%$ & Baik \\
\hline $43,75 \% \leq$ skor $<62,50 \%$ & Cukup Baik \\
\hline $25 \% \leq$ skor $<43,75 \%$ & Kurang Baik \\
\hline
\end{tabular}

HASIL DAN PEMBAHASAN

A. Validitas Petunjuk Praktikum Berbasis Masalah Memuat Literasi Sains Siswa SMP Kelas VIII

1. Hasil validasi materi terhadap petunjuk praktikum yang dikembangkan sebaga berikut :

Tabel 4.1 Hasil Validasi Materi

\begin{tabular}{ccccc}
\hline No & Validator Materi & $\begin{array}{c}\text { Aspek } \\
\text { Relevansi dan } \\
\text { Keakuratan }\end{array}$ & $\begin{array}{c}\text { Aspek } \\
\text { Penyajian }\end{array}$ & $\begin{array}{c}\text { Aspek } \\
\text { Bahasa }\end{array}$ \\
\hline 1. & $\begin{array}{c}\text { Muhammad Fadiluddin, } \\
\text { SP., S.Pd., M.Si. }\end{array}$ & $95 \%$ & $100 \%$ & $91 \%$ \\
\hline 2. & Abd. Faqih, S.Pd. & $95 \%$ & $94 \%$ & $91 \%$ \\
\hline Rata-Rata & $\mathbf{9 5 \%}$ & $\mathbf{9 7 \%}$ & $\mathbf{9 1 \%}$ \\
\hline Tingkat Validitas & $\begin{array}{c}\text { Sangat } \\
\text { Layak }\end{array}$ & $\begin{array}{c}\text { Sangat } \\
\text { Layak }\end{array}$ & $\begin{array}{c}\text { Sangat } \\
\text { Layak }\end{array}$ \\
\hline
\end{tabular}

Pada hasil validasi media aspek tampilan petunjuk praktikum memperoleh hasil sebesar $97 \%$ dengan kategori sangat layak, dan untuk aspek manfaat petunjuk praktikum memperoleh hasil sebesar $100 \%$ dengan kategori sangat layak. Hasil perolehan validasi media tertinggi pada aspek manfaat petunjuk praktikum sebesar $100 \%$ dimana dari segi manfaat petunjuk praktikum ini mempermudah siswa dalam pembelajaran. Hal ini sesuai pendapat (Sudarman, 2018) bahwa tentang pemanfaatan multimedia, informasi pengajaran melalui teks dan disertai gambar dapat meningkatkan minat belajar dalam praktikum sehingga menarik perhatian dan mudah diingat.

2. Hasil validasi media terhadap petunjuk praktikum yang dikembangkan sebaga berikut :

Tabel 4.2 Hasil Validasi Media

\begin{tabular}{cccc}
\hline No & Validator Media & $\begin{array}{c}\text { Tampilan Petunjuk } \\
\text { Praktikum }\end{array}$ & $\begin{array}{c}\text { Manfaat } \\
\text { Petunjuk } \\
\text { Praktikum }\end{array}$ \\
\hline 1. & Herowati, S.Pd.,M.Pd & $97 \%$ & $100 \%$ \\
\hline & Tingkat Validitas & Sangat Layak & Sangat Layak \\
\hline
\end{tabular}

Total keseluruhan hasil validasi petunjuk berbasis masalah memuat literasi sains siswa SMP kelas VIII dengan rata-rata skor persentase sebesar 96,4\% kategori sangat layak dan sudah valid. Hal tersebut sesuai pendapat (Hasnunidah, 2019) jika hasil validasi petunjuk praktikum telah valid dan layak untuk digunakan serta mampu mengembangkan keterampilan siswa.

Petunjuk praktikum yang dikembangkan pada penelitian dan pengembangan ini berbasis permasalahan juga memuat hal yang mendukung kegiatan literasi sains siswa. Fitur yang tersaji pada petunjuk praktikum yang berbasiskan masalah terdapat pada fitur mari simak, hal ini menjadi karakteristik pembelajaran berbasis masalah, yaitu dengan adanya permasalahan yang menjadi stimulus awal sebelum melakukan 
kegiatan praktikum dapat mengintruksikan siswa dalam mengkonstruk dan menginvestigasi pengetahuannya. Hal tersebut sesuai dengan teori Jean Piaget yang melandasi teoretis model pembelajaran berbasis masalah (Arends, 2008) bahwa pada pembelajaran, seorang pelajar harus terlihat aktif saat proses mendapatkan informasi dan mengkonstruk pengetahuan yang dimilikinya. Selain itu, petunjuk praktikum berbasis masalah ini juga memuat kegiatan yang dapat mendukung literasi sains siswa. Kegiatan yang memuat literasi sains siswa terdapat pada fitur ayo menganalisis. Fitur ayo menganalisis menginstruksikan siswa dalam menganalisis data yang diperoleh, kemudian dihubungkan dengan pengetahuan yang dimiliki siswa sebelumnya sebagai suatu pengaplikasian pengetahuan yang dimiliki siswa dalam menjelaskan suatu fenomena secara ilmiah. Fitur tersebut memuat aspek yang mendukung literasi sains yang sesuai dengan pendapat (Asyhari, 2015) literasi sains dalam penilaian PISA memprioritaskan terhadap beberapa kompetensi sains diantaranya menjelaskan fenomena alam melalui pengaplikasian pengetahuan sains pada situasi yang diberikan serta mendeskripsikan dan mendefinisikan suatu fenomena secara ilmiah.

Validitas petunjuk praktikum berbasis masalah memuat literasi sains siswa diperoleh dari hasil lembar validasi produk. Validasi produk terdiri dari validasi materi dan validasi media. Pada validasi materi yang dilakukan oleh validator ahli materi terdiri dari dua validator dengan memiliki tiga aspek yang dinilai, diantaranya aspek relevansi dan keakuratan, aspek sajian, serta aspek kebahasaan. Pada validasi media yang dilakukan oleh validator ahli media dengan memiliki dua aspek yang dinilai, diantaranya aspek desain dan aspek fungsional.

Hasil rata-rata validasi materi pada aspek relevansi dan keakuratan sebesar 95\% (sangat layak). Aspek penyajian sebesar 97\% (sangat layak). Sedangkan aspek bahasa sebesar $91 \%$ (sangat layak). Hasil validasi dengan perolehan skor presentase tertinggi pada aspek penyajian sebesar $97 \%$ yang menjadi tolak ukur dalam penelitian ini dimana karakteristik pada petunjuk praktikum yang dikembangkan dengan dibasiskan masalah dan memuat hal yang mendukung literasi sains siswa. Hal tersebut sesuai dengan penelitian (Seftia R.W., et al 2018) sebagai acuan dalam mengembangkan petunjuk praktikum sangat cocok demgan medukung literasi sains, karena literasi sains dipandang multidimensional yang tidak hanya tentang memahami pengetahuan sains, selain itu juga sesuai dengan pendapat (Fajarianingtyas \& Hidayat, 2019) bahwa pembelajaran yang menggunakan model pembelajaran berbasis masalah dalam melatih kemampuan problem solving, pengetahuan secara operasional, serta melakukan kerja kelompok dalam hal permasalahan kehidupan nyata dapat membangun literasi sains siswa

\section{B. Respon Guru Terhadap Petunjuk Praktikum Berbasis Masalah Memuat Literasi Sains Siswa SMP Kelas VIII}

Petunjuk praktikum yang dikembangkan pada penelitian dan pengembangan ini juga melihat respon guru terhadap petunjuk praktikum berbasis masalah memuat literasi sains siswa SMP Kelas VIII. Respon penelitian dari ketiga responden guru IPA yang berbeda sekolah. Terdapat dua aspek yang dinilai yaitu aspek sajian dan fungsional. Pengisian angket respon oleh guru IPA pada aspek sajian memperoleh skor sebesar 95,8\% (sangat baik). Sedangkan aspek fungsional memperoleh skor sebesar $100 \%$ (sangat baik). Hasil angket respon guru dapat dilihat pada berikut :

Tabel 4.3 Hasil Angket Respon Guru

\begin{tabular}{llcccc}
\hline No & Responden & $\begin{array}{c}\text { Penyajian } \\
\text { Petunjuk } \\
\text { Praktikum }\end{array}$ & $\begin{array}{c}\text { Manfaat } \\
\text { Petunjuk } \\
\text { Praktikum }\end{array}$ & $\begin{array}{c}\text { Persentase } \\
\text { Rata-Rata }\end{array}$ & Kategori \\
\hline 1. & Andini Dwi W, S.Pd. & $100 \%$ & $100 \%$ & $\mathbf{1 0 0 \%}$ & $\begin{array}{c}\text { Sangat } \\
\text { Baik }\end{array}$ \\
\hline 2. & Ilhamdi, S.Pd. & $91,6 \%$ & $100 \%$ & $\mathbf{9 5 , 8 \%}$ & $\begin{array}{c}\text { Sangat } \\
\text { Baik }\end{array}$ \\
\hline 3. & Abd. Faqih, S.Pd. & $95,8 \%$ & $100 \%$ & $\mathbf{9 7 , 9 \%}$ & $\begin{array}{c}\text { Sangat } \\
\text { Baik }\end{array}$ \\
\hline
\end{tabular}


Perolehan respon guru tertinggi yaitu aspek manfaat petunjuk praktikum dengan persentase skor rata-rata sebesar $100 \%$ karena dari pemanfaatan penggunaan petunjuk praktikum berbasis masalah ini dapat mendukung belajar siswa. Hal ini sesuai dengan pendapat (Hasnunidah, 2019) petunjuk praktikum dapat berfungsi sebagai penunjang pembelajaran dalam kegiatan praktikum. Hasil Respon yang diberikan responden sangat baik, sehingga produk ini bisa dapat digunakan oleh guru dan siswa pada kegiatan praktikum dengan mengintegrasikan pembelajaran berbasis masalah dan telah memuat aspek yang mendukung kegiatan literasi sains siswa didalamnya.

\section{KESIMPULAN}

Validitas petunjuk praktikum berbasis masalah memperoleh skor sebesar $96,4 \%$ (sangat layak) yang digunakan sebagaimana fungsinya. Hasil tersebut diperoleh dari dua aspek validasi, antara validasi materi dan validasi media. Pada aspek materi mendapat skor sebesar 94,3\% kategori tingkat validitas sangat layak. Sedangkan aspek media mendapatkan skor sebesar $98,5 \%$ kategori media sangat layak.

Respon guru tentang petunjuk praktikum berbasis masalah yang dikembangkan menyatakan layak untuk digunakan sebagai pedoman pada kegiatan praktikum, sumber belajar dan media bahan ajar setelah mendapat respon positif dari ketiga responden. Hasil uji yang diperoleh dari ketiga responden terhadap petunjuk praktikum berbasis masalah mendapatkan skor sebesar 97,9\% (sangat baik). Jadi, Petunjuk Praktikum Berbasis Masalah dapat layak untuk digunakan sebagaimana fungsinya.

\section{SARAN}

Saran atau rekomendasi untuk penelitian selanjutnya :

1. Penelitian ini dapat dikembangkan lagi pada materi kelas 7 dan kelas 9 yang dapat dipraktikumkan.

2. Penelitian ini dapat lebih dikembangkan dengan meninjau efektifitas penggunaan petunjuk praktikum berbasis masalah dalam meningkatkan literasi sains siswa.

3. Produk petunjuk praktikum perlu ditambah lembar yang menjelaskan tata tertib pelaksanaan dan penggunaan alat dan bahan pada kegiatan praktikum sebagai upaya meminimalisir resiko kecelakaan kerja.

4. Penyajian permasalahan pada produk petunjuk praktikum ini perlu diperjelas dan dispesifikkan kembali.

\section{DAFTAR PUSTAKA}

Abidin, D. Y. (2014). Desain Sistem Pembelajaran Dalam Konteks Kurikulum 2013. Bandung: PT Refika Aditama.

Arends, R. I. (2008). Learning To Teach (Belajar untuk Mengajar) (Edisi Ketu). Yogyakarta: Pustaka Pelajar.

Asyhari, A. (2015). Profil Peningkatan Kemampuan Literasi Sains Siswa Melalui Pembelajaran Saintifik. Jurnal IImiah Pendidikan Fisika Al-Biruni, 4(2), 179.

Budiarti, W., \& Oka, A. A. (2014). Pengembangan Petunjuk Praktikum Biologi Berbasis Pendekatan Ilmiah ( Scientific Approach ) Untuk Siswa Sma Kelas Xi Semester Genap Tahun. BIOEDUKASI, 5 no 2, 123-130. Retrieved from

Fajarianingtyas, D. A., \& Hidayat, J. N. (2019). Validitas Buku Petunjuk Praktikum Biologi Dasar Berbasis Pemecahan Masalah Untuk Mahasiswa Pendidikan Ipa Di Universitas Wiraraja. LENSA (Lentera Sains): Jurnal Pendidikan IPA, 9(2), 37-45.

Hasnunidah, N. (2019). Pengembangan Buku Penuntun Praktikum Sistam Pencernaan pada Manusia dengan Model Argument-Driven Inquiry ( $A D I$ ). July. 
KEMENDIKBUD, P. P. P. B. (2018). Pendidikan Di Indonesia Belajar Dari Hasil PISA 2018. (021), 1-206.

Meyhandoko, A. (2013). Pengembangan Petunjuk Praktikum Kontekstual dengan Pemanfaatan Kondisi Lingkungan Lokal dalam Pembelajaran Materi Pencemaran di SMA N 2 Rembang.

Pertiwi, U. D., et al. (2018). Pentingnya Literasi Sains Pada Pembelajaran Ipa Smp Abad 21. Indonesian Journal of Natural Science Education (IJNSE), 1(1), 24-29.

Prasetyono, R. N., \& Trisnawati, E. (2018). Pengaruh Pembelajaran IPA Berbasis Empat Pilar Pendidikan terhadap Kemampuan Berpikir Kritis. JIPVA (Jurnal Pendidikan IPA Veteran), 2(2), 162.

Seftia R.W., et al. (2018). Kelayakan Putik Berisi (Petunjuk Praktikum Ipa Berbasis Literasi Sains) Untuk Peserta Didik Sekolah Dasar Kelas V. Education and Human Development Journal, 3(2), 111-120.

Sudarman, S. Muhammad. (2018). Pengembangan Ebook Panduan Praktikum Sebagai Suplemen Pendukung Konferensi Antar bangsa islam Borneo ke-10 2017 / ISBN978-9670828-18-3 Muhammad Saparuddin. March.

Sugiyono, P. D. (2015). Metode Penelitian Pendidikan. Bandung: Alfabeta.

Sunarti. (2018). Pengembangan Buku Petunjuk Praktikum Berbasis Inkuiri Dilengkapi Word Square Berintegrasi Sains dan Islam Pada Materi Keanekaragaman Hayati di MA Islamiyah Attanwir. Skripsi : Universitas Islam Negeri Walisongo Semarang.

Susanti, A. A. (2019). Efektivitas Lkpd Terintegrasi Nilai Islami Pada Pembelajaran Berbasis Masalah Untuk Meningkatkan Kemampuan Literasi Sains. 02(1), 64-78.

Thiagarajan, et al. (1974). Instructional Development for Training Teachers of Exceptional Children. Indiana University Bloomington. 